\title{
Türkiye`de Neoliberal Devletin İnşa ve Muhafazasında Çanakkale Savaşı Söyleminin Rolü Üzerine Bir Tartışma \\ *
}

\author{
Elif Gezgin \\ Lund Üniversitesi / Çanakkale Onsekiz Mart Üniversitesi
}

Öz

Bu metinde Çanakkale Savaşı'yla ilgili tarihsel anlatıdaki değişim ve yoğunlaşma, konunun Türkiye'de neoliberal devletin inşa ediliş süreciyle olan ilişkisi çerçevesinde incelenmektedir. Konuyla ilgili tartışma Wacquant in sentor devlet (centaur state) kavramsallaştırması üzerinden yürütülmekte ve Çanakkale Savaşı vurgusunun günümüz Türkiye'sinin neoliberal ihtiyaçlarına nasıl hizmet ediyor olabileceği sorgulanmaktadır. Bu arka plan çerçevesinde metinde güncel Çanakkale Savaşı anlatısının; Batı karşıtı ideolojileri destekleme, düşman yaratma ve hakim rejime destek toplayıcı bir araç olarak kullanılma işlevleri ele alınmıştır. Bunun yanı sıra, söz konusu eğilimin, savaşın yer aldığı kente, yani Çanakkale'ye olan toplumsal ve mekânsal etkilerine değinilmiştir. Çalışmada, Wacquant'ın kapatma (incarceration) vurgusundan hareketle, 'ideolojik kapatma' olarak adlandırabileceğimiz bir kontrol biçiminden daha söz edebileceğimiz öne sürülmekte ve Türkiye örneği üzerinden ele alınan bu tür bir ideolojik kapatmanın, tarihsel referansların ele alınma ve kitlelere yansıtılma biçimiyle olan olası ilişkisine dikkat çekilmektedir. Metnin genel amacı, tarihin kitlelere yansıtılışı ile iktidar ilişkileri arasındaki etkileşimleri yerel bir örnek üzerinden ve neoliberalizm tartışmaları çerçevesinde sorgulamaktır.

Anahtar Kelimeler: Neoliberalizm, Wacquant, sentor devlet (centaur state), ideolojik kapatma, Çanakkale, Çanakkale Savaşı. 


\title{
A Discussion on the Role of the Gallipoli War Narrative in Constructing and Protecting the Neoliberal Government in Turkey
}

\author{
Elif Gezgin \\ Lund University / Çanakkale Onsekiz Mart University
}

\begin{abstract}
In this paper, I examine why the Gallipoli War narrative has become increasingly important over the last two decades, and how this visible tendency is related to the construction and protection of the neoliberal government in Turkey. I frame the discussion by utilizing Loïc Wacquant's concept of the 'centaur state' and focus on how Gallipoli narratives meet the requirements of the neoliberal order in contemporary Turkey. Besides, I discuss the issue within the framework of its effect on the territory where the war took place; namely, Çanakkale. In this way, I seek to answer my research question by studying a local case and drawing on the scholarship on neoliberalism, as well as interrogating the relationship between the power relations and the way history is passed down from one generation to the next and from the state to the public. I argue that in the Turkish case, there is an 'ideological incarceration', in addition to incarceration, which helps the centaur state to obtain and protect its legitimacy. Thus, the Gallipoli War narrative acts as a significant historical reference to enable this current ideological incarceration of Turkish society, specifically by: i) supporting anti-Western ideologies; ii) creating enemies; and iii) providing political support for the dominant regime.
\end{abstract}

Key words: Neoliberalism, Wacquant, centaur state, ideological incarceration, Çanakkale, Gallipoli War. 


\section{Giriş}

"Grev denilen olayı ortadan kaldırdık" 30 Aralık 2018, Recep Tayyip Erdoğan" ${ }^{1}$

2019 yılındayız. Katı olan her şeyin buharlaştığı bir dünyanın çok daha ötesindeyiz. Gözümüzün önünde ne olup bittiğini dahi görmekte zorlandığımız bir bulanıklık içerisinde, ardı arkası kesilmez dönüşümlerin takibinin neredeyse imkansızlaştığı bir çağa tanıklık ediyoruz. Dün kutsal addedilenin bugün ayaklar altına alınabildiği, bugünün değerlerinin ise aynı anda pek çok şey ifade edebildiği, yarını belirsiz ve son derece huzursuz bir çağ bu. Sosyal bilimler alanı da bu karmaşadan payını alıyor mutlaka. Pek çok şeyin aynı anda doğru kabul edilebildiği böylesi bir alanda, geçmişten aşina olduğumuz belirlilik hissine kavuşmak için çabalamanın anlamı da bir başka sorgulama konusuna dönüşmüş durumda.

Neoliberalizm, sosyal bilimler alanındaki temel tartışmalarda söz konusu karmaşanın hissedildiği uğrak kavramlardan biri. Neoliberalizmi bir türlü dikiş tutmayan kapitalist sistemin, kendini sermaye lehine yeniden düzenleme çabasının bir ürünü olarak değerlendirebiliriz. Gamble’ın ifadesiyle, global arenanın son kırk yılına yansıyan en önemli eğilimlerden biri "ekonomik liberalizmin hem bir politik ekonomi formu hem de bir politik ideoloji olarak yeniden kurgulanışı" olmuştur. "Sermayenin bir kez daha zaferini ilan edişiyle" şekillenen fikir ve politikaların toplamına ise kısaca neoliberalizm diyoruz (2006, s.20).

Neoliberalizm, bir yanıla yaşamımıza muhakkak derinden nüfuz eden, ancak bunun nasıl ve neden gerçekleştiği konusunda disiplinler arası muhtelif tartışmaların sürdügü bir çalışma alanı. Kavramın yukarıda sözü edilen güncel karmaşa halinin pek çok boyutuna aynı anda açıklama getirme amacıyla işe koşulması, bu alanda pek çok eleştirel yorumun gündeme gelmesine neden olmakta. ${ }^{2}$ Yine de neoliberalizm, günümüz karmaşık düzenine, bu düzen üzerinde sahne alan iktidar ilişkilerine ve bu ilişkilerin gündelik yaşam üzerindeki etkilerine dair bir kaç söz söylemek isteyenlerin kaçınılmaz uğrak noktalarından biri. Bu öğeler arasında-

${ }^{1}$ http://www.cumhuriyet.com.tr/haber/siyaset/1186248/Erdogan Grev denilen olayi orta dan kaldirdik.html (30 Aralık 2018)

${ }^{2}$ Kavramın analitik gücünü tartışan ve konuyu Türkiye bağlamını da gözeterek ele alan bir analiz için bkz. Yazıcı, 2013. 
ki geçişliliğe ve her birinin ötekini karşıllklı olarak etkileyebilme haline yönelik tartışmalar ise neoliberalizme dikotomik bir bakış açısından arınarak yaklaşma gerekliliğinin, yani ilişkisel bir bakış açısına olan ihtiyacın altını çizmekte. Bu noktada neoliberalizmi, 'neoliberalleşme' olarak tanımlama eğilimi de ayn ihtiyacın bir ürünü olarak yorumlanabilir. Neoliberalleşme kavramını ön plana çıkaran eleştirel literatür, kavramı verili bir açıklama aracı olarak kullanmak yerine, neoliberalleşme sürecinin kendisini araştırmanın önemine işaret etmekte. Yazıcı'nın ifade ettiği gibi, burada vurgulanmak istenen şey "neoliberalleşmenin her zaman belli tarihselcoğrafi bağlamlarda, spesifik sosyal-kültürel formasyonlar ve farklı siyasi öncelikler ve projeler ile etkileşim ve kesişim içinde, belli toplumsal aktörler tarafından üretilen bir siyasi proje olarak ele alınmasının gerekliliğgi"dir $(2013$, s.11).

Kavramın yaygin olarak bilinen temel boyutu; ekonomik sistemdeki ve emek piyasasındaki dönüşüm nedeniyle Keynesçi refah devleti modelinden neoliberal devlete geçişe karşılık gelmekte. Peki, farklı siyasal ya da kültürel dinamikler ile etkileşim içerisinde cereyan eden neoliberalleşme ile etki alanı arasında tek taraflı bir iliş̧i mi söz konusudur, yoksa süreç karşılıklı bir etkileşime mi dayalıdır? Ya da global arenada piyasanın ön plana çıkarıldığı ve devletin geri plana çekildiği bir tablodan bahsetmek gerçekten de mümkün müdür? Bu noktada neoliberalizmin (ya da neoliberalleşmenin) "genel/afaki tanımlarının ötesine" geçmenin ve kavramın "toplumsallaşma mekanizmalarını" ele almanın (Bora, 2007) önem taşıdığı görülüyor.

Tolstoy, "mutlu aileler birbirine benzer, her mutsuz ailenin ise kendine özgü bir mutsuzluğu vardır" der (1922, s.1). Denetimsizleştikçe, bireyleri aynılaştırıcı ve yatıştırıcı gücünü kaybeden bir emek piyasasının sonuçları göz önüne alındığında, bugün birbirine benzeyen mutlu toplumlardan ziyade; ortak noktanın bir tür kriz hali içerisinde olma durumu olduğu, ancak her bir toplumun farklılık gösteren sıkıntılarla boğuştuğu bir küresel konjonktür söz konusu. Sürecin tarihsel arka planına bakıldığında, 1970'lere dek, en azından sanayi toplumlarında, sosyal devlet anlayışının yarattı̆̆ iklimin topluma; iş güvencesi, belirli bir hukuki düzen çerçevesinde yaşamanın yarattı̆̆ güvenlik hissi, birbiriyle benzerlik arz eden yakın çevre üyelerinden oluşan sosyal ortam ya da ücretsiz eğitim/sağlık gibi olanaklar sağlayarak, bugüne kıyasla çok daha ideal/kestirilebilir bir ortam sunduğu söylenebilir. Bugün ise belirsizlik ve dağılmışlı̆̆ın gündelikleştiği bir sosyo-ekonomik zemin söz konusu. 
Bu noktada neoliberalleşmenin bağlamsal düzeyde, yani yerelde nelere yol açtığını incelemek önem taşıyor. Neoliberal dönüşümün etkisi, bugün global düzeyde yıkım yaratsa da, daha fazla sermaye gücüne sahip olan ülkelerin bu sarsıcı uygulamalardan görece azade kaldığını -ya da sürecin şiddetini daha az hissettiğini- hala söyleyebiliriz. Gamble'ın İngiltere örneğini ele alırken dikkat çektiği gibi, sermaye gücüne sahip bu gibi ülkeler, yıkıcı neoliberal uygulamaları "kendi sınırları içerisinde yürürlüğe koymaktansa, çevrelerindeki 'başarısız devletlere' dayatmayı daha kolay/elverişli bulurlar" (Gamble, 2006, s.27). Üstelik, bu gibi ülkelerin üretimlerini kıyı (offshore) sistemine kaydırmaları ve finansallaşma sürecinin toplumları tüketim ve kredi kullanımı odaklı bir gündelik yaşama sürüklemesi, en çok da bu 'başarısız' devletleri etkilemekte.

Ben bu noktada, söz konusu çevre devletlerden biri olan Türkiye örneğine odaklanacă̆ım. Sistemin ortak çıkarlarından kaynaklanan bazı benzer örüntülere rağmen, bu süreçte ele alınan her bir coğrafyanın kendi sosyo-ekonomik dinamiklerinin ve direniş/adaptasyon biçimlerinin dünyanın her köşesinde farklı 'mutsuzluklar' yaratmış olduğunu düşünüyorum. Dolayısıyla Türkiye'yi, kendi bağlamında, yani kendine özgü mutsuzluğu içerisinde ele almak gerektiğini düşünüyorum. Bu nedenle, sürecin Türkiye'de nasıl şekillenmekte olduğunu ve ülkenin son 40 yılına damgasını vuran gelişmelerin neoliberalleşme süreçleriyle olan ilişkisini/iç içeliğini anlamak önem taşıyor.

\section{Türkiye'de Neoliberalleşme}

Türkiye'nin neoliberalleşme süreci, 80'li yıllar itibariyle ele alınmakta. 24 Ocak kararları olarak bilinen ve IMF güdümünde uygulamaya konan sürecin devamında -farklı ülkelerdeki emsallerine benzer şekilde kanlı bir darbeyi takiben- demokratik bir sistem içerisinde kabul görmesi mümkün olmayan uygulamaların sisteme dayatılmaya başlandığı bir süreçle karşılaşıyoruz. Darbe, "getirdiği yeni anayasal ve yasal düzenle birlikte yarattığı güçlü cumhurbaşkanı, yüzde on barajı, kanun hükmünde kararname çıkarma yetkisi ve ikili bürokrasi eliyle, yürütmeyi yasama karşısında güçlendirmiştir" (Haspolat, 2016, s.404). Böylece yürürlüğe konması mümkün hale gelen temel dönüşümlerden / uygulamalardan bazıları; faiz kontrollerinin kaldırılması, döviz ticaretinin serbestleştirilmesi, 1989 yılı itibariyle sermaye hareketlerinin serbest bırakılması ve 1996 yılı itibariyle AB ile 
Gümrük Birliği anlaşmasıyla diş ticaretin serbest hale getirilmesi olarak sıralanabilir (Arın, 2007). Genel olarak bu dönem, çeşitli gerekçelerle "sermaye lehine ve emek aleyhine düzenlemelerin" meşruiyet kazanmasına yönelik büyük bir çabanın hâkim olduğu bir sürece işaret etmekte (Bedirhanoğlu ve Yalman, 2009, s.247). 2000'li yıllarda -2001 krizini takiben- Adalet ve Kalkınma Partisi'nin (AKP) iktidara gelişi ise “Türk siyasetinde Özal ile başlayan sürecin, neoliberal dönüşümün, 1990'lardaki aksamalardan sonra, tamamlanması" olarak kabul edilir (Uzgel, 2006, s.7). Bu süreçte Türkiye, " 1980 'de başlayan radikal piyasa odaklı reform stratejilerini ve Washington uzlaşmasının felsefesini takip etmeyi sürdürdü"3 (Herr ve Sonat, 2014, s.35). Bununla birlikte bu dönem, devletin yeniden yapılandırılmasının hız kazandığı, dolayısıyla neoliberal reformların çok daha hızlı ve sistemli bir biçimde uygulanmaya başladığı bir dönem oldu. Bu nedenle 2000'li yıllar, “kamu-özel dengesinin ikincisi lehine bozulduğu, borçların ancak ülkeye düzenli sıcak para çekilebilmesi ve finansal yatırımlar için kâr istikrarının sağlanabilmesiyle döndürülebildiği, dolayısıyla devlet, sermaye ve emek açısından 'istikrar'ın tanımının giderek ortaklaştığı" bir süreç olarak karşımıza çıkmakta (Bedirhanoğlu, Çelik ve Mihc1, 2017, s.14). Bu süreç, 82 Anayasası sonrası başlayan gücü tek elde toplama çabasının belirginleştiği ve bugün başkanlık sistemiyle birlikte zirveye ulaşan neoliberal -ve kaçınılmaz biçimde otoriter- bir dönüşümü ifade ediyor.

2010'lardan bu yana küresel politikalara paralel bir biçimde Türkiye'nin de finansallaşmanın yoğun etkisi altına girdiğini görüyoruz. Bu süreçte "tüketici kredilerindeki ve kredi kartı borçlarındaki artışın" çarpıcı bir düzeyde olduğunu ve "bu iki kalemdeki borçların toplamının GSYH'ye oranının 2002' de yüzde 1,8'den 2012' de yüzde 17,3'e fırladığını" görüyoruz (Güngen, 2007, s.29). Neoliberalizm "ücretler yükseltilmeden herkesin tüketici yaşam tarzını benimseyebileceği" kurgusuna dayandığından (Mason, 2016, s.49), bu süreç Türkiye'de de kendisini sıra dışı bir biçimde ortaya koyuyor: Tüketim olanaklarının fazlalaşması ve kredi imkânlarında ciddi bir artış. Böylece karşımıza çıan bu ilginç ve bir o

\footnotetext{
${ }^{3}$ Gelişme sürecinde devletin rolünün önemini tanıma konusunda belirgin girişimlerle anılan ve Post-Washington uzlaşması olarak adlandırılan tartışmalar da bu süreci ele alırken önem taşımaktadır. Konuyla ilgili daha detaylı bir analiz için bkz. Ziya Öniş, Fikret Şenses (2005) Rethinking the Emerging Post-Washington Consensus. Development and Change 36(2):263-290.
} 
kadar da ironik sahnede; yani emek karşıtı uygulamaların sürdüğü, ücretlerde herhangi bir gelişmeden söz etmenin mümkün olmadığı ve gelir eşitsizliğinin çı̆̆ gibi büyüdüğü bir Türkiye'de, korkunç bir kredi patlaması ve inanılmaz bir tüketim kültürü topluma hâkim olmuş durumda. Teknolojinin de gelişimiyle birleşerek her kesime ve bütçeye uygun hale gelen ürün hatları, topluma pompalanan tüketim çılgınlığını besledi ve bu ürünlere erişmenin yolu olarak kredi satışları ön plana çıarıldı. Son 25 yılda neoliberalizm, bir yanıyla "dünyanın bugüne dek görmüş olduğu en geniş gelişim patlamasını" tetiklerken, diğer yandan "eşitsizliği 100 yıl öncekine yakın bir duruma yeniden getirdi [...]" (Mason, 2016, s.14).

$\mathrm{Bu}$ süreçte devletin, piyasaların mevcut gelişimine uyumlu bir yörüngede hareket ettiğini görüyoruz. "Finansal sermayenin öncelikli projelerine uygun bir hat izleyerek" gelişen devlet uygulamaları; "finansal sektörün kayıplarının toplumsallaştırılması, neoliberal siyasal iktisadi politikaların alternatifsiz olarak savunusu, uluslararası siyasal iktisadi gündemlerin aktarımı ve uluslararası 'en iyi uygulamalar'ın kısmen değiştirilerek uyarlanması, temel önem taşıyan konularda siyaset yapımı-geliştirme ve uygulamanın toplumun geniş kesimlerinin katılımı ve bilgilendirilmesinden sakınılarak yapılması vb." olarak sıralanabilir (Güngen, 2017, s.40). Bugün yaşanan global kriz hali ise başlangıçta oldukça parlak gelişmelere işaret eden ve toplumda bir 'bolluk' algısı yaratan neoliberalleşme sürecinin, sistemde istenen sonuçları daha fazla sürdüremediğine işaret etmekte. Yaşanan ekonomik kriz, son yılların ısrarlı tüketim teşviklerinin yarattığı 'gelişme' ya da 'büyüme' illüzyonunu ortadan kaldıracak düzeyde. Peki, bu süreçte günümüz Türkiye'sinde güvencesiz koşulların ve tüketim/borç tuzağının pençesinde var olmaya çalışan 'borçlu birey'in akıbeti nedir? Durumun yarattığı korkunç yaşam ve çalışma koşullarında var olmayı ve emek vermeyi sürdürmesi için alt sınıfların rızası nasıl kazanılır? Ve bu metin açısından daha da önemlisi; söz konusu koşullarda yaşamını sürdürme gayretindeki bireylerden oluşan bir toplumun idaresi nasıl sürdürülebilir? Kriz sürecinde, "toplumsal üretim ilişkilerindeki konumu nedeniyle değil, harcama ve yatırım kararlarının sonucu olarak borçlu gösterilen" bireyin bu konumu şüphesiz ki "piyasa şiddetine tepkinin yoğunlaşmasının zeminini hazırlamaktadır" (Güngen, 2017, s.41). Düşük gelir grubunda yer alan kesimleri, tüketimle ve düşük faizli kredilerle buluşturarak beslenen sistemin, artık bunu sürdüremediği bir çözülme noktasına gelmesi akıllara kaçınılmaz olarak sistemin kendisini boşluğa düşen bu kitle karşısında nasıl koruyacağına dair bu soruları getirmekte. Piyasa şiddetine 
tepkinin yoğunlaşma riski gözetildiğinde, bu sorulara doğru yanttlar bulabilmenin sermaye için elzem olduğunu iddia edebiliriz. Bu noktada otorite kavramının ne denli büyük bir önem taşıyacağını ise peşinen tahmin etmek mümkün.

Sosyolog Loic Wacquant, neoliberalleşme ile otoriterleşme arasındaki ilişkiyi ele alışıyla bu alandaki tartışmalara önemli bir katkı sağlıyor. Düşünürün, birazdan ele alacağımız, neoliberal devlet inşası üzerine yazdıklarına paralel biçimde; Türkiye'de de neoliberalleşme sürecinin hız kazandığ 2000 'li yıllar itibariyle, devletin görünürlügünde ve otoritesinde hatırı sayılır bir yükselişe tanık olduk. Bu nedenle bu metinde konuyu Wacquant'in neoliberal devlet kavramsallaştırmasından yola çıkarak, yine 2000'li yıllar itibariyle gündeme taşınma sıklığı ciddi bicimde artan Çanakkale Savaşı örneği üzerinden irdelemeye çalışacağım. Amacım, Türkiye'de neoliberal otoriter devletin inşa sürecinde ve bu sürece yansıyan küresel krizin ve onun yarattığı acil rıza ihtiyacının yönetiminde Çanakkale Savaşı anlatısının ne gibi işlevselliklerinin olabileceğini sorgulamak. Aynı zamanda, son yıllarda bu tarihsel olaya eklemlenen yeni ideolojik vurguların kente nasıl yansıdığını ele alacă̆ım. Bunun için önce Wacquant'ın neoliberalizm ve sentor devlet (centaur state) kavramını ele alışına kısaca değinelim.

\section{Wacquant, Neoliberalizm ve Sentor Devlet}

Wacquant neoliberalizmi ele alışında; ekonomi, devlet ve bürokrasi alanları arasındaki çetrefilli ilişkiyi ön plana çıkarışıyla, bu alandaki tartışmalara hak ettiği ilişkiselliği kazandıran önemli düşünürlerden. O neoliberalizmi, "piyasa, devlet ve vatandaşlık arasındaki ilişkiyi, yukarıdan aşağıya doğru olacak şekilde yeniden oluşturmayı amaçlayan ulusötesi siyasal bir proje" olarak tanımlar (Wacquant, 2010, s.213). Wacquant için neoliberalizm, devletin piyasa koşullarına uygun bir biçimde idare edilmesi anlamı taşır. Bu da "devletin, piyasanın ve vatandaşlığın eklemlenmesini içerir; ki bu, piyasanın vatandaş üzerindeki damgasını dayatması için devleti dizginleyen bir eklemlenmedir. Dolayısıyla bu üç alanın birden analitik çerçevemize dâhil edilmesi şarttır" (Wacquant, 2012, s.71). Bu analiziyle yaygın söylemin dişına çıkan düşünür, neoliberalleşmenin devletin küçülmesinden ziyade yeniden şekillenmesine neden olduğunu ortaya koyar 
(Wacquant, 2012). ${ }^{4}$ Yani burada, güçlenen piyasa karşısında geri çekilen bir devlet değil, piyasa ile eklemlenerek "metalaşmayı teşvik eden, piyasayı destekleyen" güçlü bir devlet biçimi söz konusudur (Wacquant ve Akçaoğlu, 2014, s.68).

Güç ve zenginliğin derişiminin pekişmesine ve devlet gücü ile piyasa arasındaki ilişkiye odaklanan bu yaklaşım, bu metinde önemli bir yer tutmakta. Önceki yüzyılda, piyasa ile olan ilişkisinin kriz durumlarında gereken müdahalelerde bulunmayla sınırlı olduğu büyük oranda kabul edilen refah devleti modelinin, yerini piyasa ve metalaşma süreçleri ile alenen iç içe olan ve gücünü büyük oranda piyasanın selameti için kullanan ve pekiştiren yeni bir devlet yapılanmasına bıraktığı görülüyor. Bunun devamında ise Wacquant'ın sentor devlet olarak tabir ettiği yapı ortaya çıkıyor (Wacquant, 2010, s.217). Yunan mitolojisinde yarı insan yarı at görünümündeki bir yaratığa karşılık gelen sentor terimi, Wacquant'ın devlet kavramlaştırmasında birbirine karşıt iki özelliği bulunan bir yapı olarak tanımlanır. Neoliberal devlet kavramına karşılık gelen sentor devletin işleyişi, "tepedekiler ve aşağıdakiler için farklılık gösterir. O tepede liberal, aşağıda ise cezalandırıcıdır" (2014, s.1690). Yani, "yukarıda, ekonomik ve kültürel sermaye sahiplerinin kaynaklarını arttırmak ve yaşam olanaklarını genişletmek üzere hareket eden, motive edici ve 'özgürleştirici'” bir yüze sahip olan bu devlet modeli; "aşağıda; konu derinleşen eşitsizlik ve yayılan iş güvencesizliği ve etnik kaygı yüzünden istikrarsızlaştırılmış toplulukları yönetmeye gelince, [...] cezalandırıcı ve sinırlayıcıdır" (Wacquant, 2012, s.74). Bu tür bir devlet yapılanması, iş güvencesi ve sosyal hakların ortadan kaldırılmasının yarattı̆̆ kargaşayı ve bu sorunlardan kaynaklanan toplumsal sorunları normalleştirici bir işleve sahiptir. Yani "neoliberal zamanlarda devlet konu dışı bırakılmak yerine, neoliberal toplumsal düzeni şekillendirmekte aktif bir rol sahibi olmuştur" (Woolford ve Nelund, 2013, s.298).

Sentor devlette 'yoksulluğun cezalandırılışı' süreci, "vatandaşlığı sınıf hatları boyunca parçalara böler, yurttaşlığa dair güveni temelinden yıkar ve cumhuriyet ilkelerinin yozlaştırılması sürecini keser. Nihayetinde kurulan yeni sosyal güvencesizlik devleti, neoliberalizmin temeldeki demokra-

\footnotetext{
${ }^{4}$ David Harvey, devlet gücünün azalmadığı fakat global neoliberalizm süreci ile devletin yeniden düzenlendiği yönündeki çalışmaları ile bilinen bir diğer önemli düşünürdür. Daha detaylı bilgi için bkz. David Harvey (2007) A Brief History of Neoliberalism. Oxford: Oxford University Press.
} 
siyi aşındırıcı etkisini ortaya çıkarır" (Wacquant, 2010, s.218). Her koyunun kendi bacağından asılacağı bu nizamda, kaçınılmaz bir biçimde ortaya çlkacak olan kaos gözetilerek, bunu dizginlemeye uygun yeni bir ideal vatandaş tipi yaratılması önem kazanır. “Neoliberalizmin yarattı̆̆ yoksulluk ve yoksunluktan muzdarip alt-sınıfların sisteme içerilmesi ya da düzene karşı tehdit olmalarının önlenmesi adına devlet yeni mekanizmalar yaratmakta; hatta bunun da ötesinde yeni bir toplum mühendisliğine soyunmaktadır" (Bedirhanoğlu, Dölek ve Hülagü, 2016, s.17). Bu noktada Wacquant'ın iddiası; oluşan bu yeni düzen içerisinde devletin birey üzerindeki koruyucu rolünün yerini disipline edici, otoriter ve cezalandırıcı bir role bıraktığıdır. Bu anlamda küçülen ya da geri planda bırakılan bir devlet değil, gücünü arttıran, ancak bu gücü belirli bir kesim üzerinde ve sermaye çıkarlarını gözeterek kullanan bir devlet söz konusudur. Bu aynı zamanda manipülatif bir devlet olmayı da gerektirecektir çünkü bu yeni yapılanmanın bekası, vatandaşlarına maruz kaldıkları güvencesiz ve eşitsiz koşulları kabul ettirmesine bağlıdır. Wacquant’ın ifade ettiği gibi:

Devlet toplumsal ve ekonomik bir güvence sağlamadığı koşullarda otoritesini yeniden sağlamlaştırmak zorundadır. Bu yeni koşullarda siyasi elitler meşruiyet açı̆̆ı sıkıntısı çekiyor. Sermayenin hükümranlığını ilan ettiği koşullarda devlet iktidarını nasıl sahneler? Bütçenizi AB belirlerken, ekonomik sermaye akışı sizi gereksiz k1larken, vatandaşlarınıza iktidarda olduğunuzu nasıl anlatabilirsiniz? Devlet iktidar kapasitesini yeniden canlandırmak için ceza devletini etkin hale getirir (Wacquant ve Akçaoğlu, 2014, s.69).

Wacquant ceza kavramını bu şekilde öne çıkarırken; sistemin yarattığı toplumsal yıkımın sonuçlarının, yine bu koşulların mağdurlarına yönelerek onları mevcut alanlarına hapseden otoriter bir ideolojiye işaret etmekte. Bu minvalde Türkiye'de de, Wacquant'in saptamasına paralel şekilde ve Bedirhanoğlu'nun da ifade ettiği üzere; "başta emek olmak üzere, neoliberal politikaların kaybeden kesimleri üzerinde kurulan tahakküm biçimlerini koruyup yeniden üretilebilecek güçte bir devlet yapısı" oluşturulmaya çalışılmaktadır (2009, s.48). Daha önce değinildiği gibi, Türkiye'de neoliberalleşme sürecinde çalışma hayatına ve o güne dek kazanılmiş haklara geri döndürülmesi güç düzeyde zarar veren uygulamaların, uluslararası rekabet gücü kazanma gerekçesiyle ücretleri ve diğer hak edişleri baskı altında tuttuğunu görüyoruz. AKP yönetimiyle birlikte "güvencesiz istihdam koşulları, ataerkil ve İslamcı çalışma ilişkileri yoluyla, örgütsel sınıf kapasitesini yasaklayıcı etkisiyle desteklenmiş" olsa da 
(Gürcan ve Mete, 2017, s.87), zaman içerisinde bu müdahalelerin yetersiz kalması, dolayısıyla devletin tüm alanlarda, bir bütün olarak ve hatta kendi yapısını da dönüşüme uğratacak düzeyde otoriterleşmesi kaçınılmaz görünmekte.

Türkiye tarihine baktığımızda, özellikle 1982 Anayasası'yla belirginleşen bir otoriter devlet yapısının halihazırda söz konusu olduğunu görüyoruz. Ancak, son döneme dek, parlamenter bir rejimin (koşulları tartışılsa da) ülkedeki varlığı, süreci bugünkü koşullardan ayırıcı nitelikte. Dolayısıyla Türkiye'yi rejim değişikliğine doğru götüren son yirmi yıllık süreçte neoliberalleşmenin devlet yapısında bugün yarattı̆̆ etki, mevcut tarihsel otoriter altyapının sınırlarını aşmakta, onu hem daha görünür kılan, hem de sermaye lehine motivasyonlarının yoğunlaştığı ve belirginleştiği bir yapıyla tezahür etmekte. Burada mesele kimin iktidarda olacağ1 ya da hangi ideolojik görüşe asla zeval gelmeyeceği gibi kaygıların ötesine geçip, kimin sermayeyi koruyacağ ve dolayısıyla ideolojisi ne olursa olsun, hangi yapının mevcut piyasaların ülke içindeki bekasını sürdürüp pekiştirebileceği sorusuna dönüşüyor. Böylece zemin kayganlaşırken, geçmiş otoriter eğilimlerin görece tutarlılığı yerini her an yeniden pozisyon alınmasını gerektiren bir dönüşümler silsilesine ayak uydurabilme becerisine bırakıyor. ${ }^{5}$

Böylesi kaygan bir zeminin toplumda yarattığı kafa karışıklığı ise mevcut otoriteye idrak edilemezlik -ve böylece sorgulanamazlık- gibi avantajlar kazandırıyor. Süreci takip edebilecek ve kendi konum ve koşullarının kontrolünü sağlayabilecek bir vatandaşlıktan söz etmek ise imkansızlaşıyor. Bu süreçte neoliberal dönemin tipik bir özelliği olarak "polis, cezaevleri, hapishaneler gibi cezalandırma mekanizmalarının devletin merkezi bileşenleri haline geldiğini görüyoruz" (Wacquant, 2009, s.304). Aynı süreçte, yasanın dönüşümü ve gücün yürütme alanında toplanması ise hâlihazırdaki bu eğilimi sağlam temellere dönüştüren gelişmeler arasında. Yasal süreçler yoluyla ya da sermaye sahiplerinin gücüne dayalı diğer yaptırım türleri ile otorite kurma, korkutma ve yıldırma Türkiye'de karşılaşılma sıklığı her geçen gün daha da artan baskı mekanizmaları halini almış durumda. Bilhassa yargı alanının son yılların önemli dönüşümlerine sahne olduğunu görüyoruz. Bu alana özellikle, devletin cezalandırıcı, güç-

\footnotetext{
${ }^{5}$ Popülizmle ilgili daha fazla bilgi için Türkiye örneğini de içeren güncel bir yayın örneği olarak bkz. Daniel Stockemer (Ed). Populism Around the World: A Comparative Perspective (2019). Cham: Springer.
} 
lü yapısının olmazsa olmazlarından biri olarak yürütmenin güçlendirilmesi çabasının yarattığı gerilimler yansıyor. Aynı zamanda 'Yeni Türkiye' söylemiyle birleşen, devletin yeniden yapılandırılması sürecine dair belirsizlikler söz konusu. Başkanlığa geçişle birlikte kısmen netleşen ancak pek çok yönden belirsizliğini koruduğunu iddia edebileceğimiz bir tür ara rejimi andıran bu süreçte, otoriterleşme gündelik hayatın her alanına yayılarak, farklı tonlarda karşımıza çıkıyor. Neoliberalizm ve siyasal İslam bütünleşmesinin belirginleştiği bu dönemde, yeni Osmanlıcı söylemin zirve yapışı ise sürecin merkezi bir boyutu. Bununla birlikte bugünkü durumu tek bir eğilimle açıklamak yerine; bir kolaj gibi, koşullara göre farklı anlatı parçalarının devşirildiği dinamik bir süreç olarak değerlendirmek mümkün. Yani sistemin -muhafazakar ve yeni Osmanlıcı çizgide seyretmekle birlikte- çeşitli tarihsel referanslar ve bunlardan edinilen/dönüştürülen bilgi stokları yoluyla, sosyo-ekonomik koşullara uygun yeni anlatıların sahneye girip çıktığı hareketli bir var olma mücadelesi içerisinde olduğunu öne sürebiliriz.

Bu noktada yerele dönerek söylemek istediğim ise, son yıllarda Çanakkale üzerinde yaratılan özel vurgunun, neoliberalizm ve siyasal İslam bütünleşmesinde bugünün ihtiyaçlarına başarılı bir biçimde karşılık veren ideolojik bir temel sunuyor olabileceği. Yani Çanakkale Savaşı anlatısının, devletin bu yeni formuna kaynaklık eden kurucu bir referans olarak ele alınabileceğini öne sürüyorum. Bu minvalde yazının devamında, 'Çanakkale ruhu'nun Türkiye'nin güncel siyasetinde bugün ne gibi işlevlere sahip olabileceğini tartışacağım.

\section{Güncel Çanakkale Savaşı Anlatısının Neoliberal Düzen İnşasındaki Olası İşlevleri}

“Çanakkale başka... Çanakkale bizim ilham kaynă̆ımız, Çanakkale bizim istikamet kaynağımı" 18 Mart 2018, Recep Tayyip Erdoğan

Otorite inşa etmede ülke çoğunluğunu oluşturan kesimin kolektif duygularına hitap eden popülist söylemlerin önemli bir rolü bulunur. Türkiye bağlamında bu kesim şüphesiz ki muhafazakar kitledir. Muhafazakar

\footnotetext{
${ }^{6}$ https://tr.sputniknews.com/turkiye/201803181032683283-erdogan-afrin-operasyonu/ (18 Mart 2018)
} 
kitleye hitap edecek ideolojiyi şekillendirmede, en az güncel söylemler kadar tarihsel anlatılar da önem taşır. Bu bölümde bugünkü Çanakkale Savaşı anlatısının süreçteki olası işlevlerini; üç başlık altında tartışacağım. Birinci bölümde savaş anlatısının Batı karşıtı ideolojiyi destekleyen rolü, ikinci bölümde bu anlatının düşman yaratma işlevi ve son olarak ise hakim rejime destek toplayıcı bir propaganda aracı olarak kullanılışına değineceğim.

\section{Batı-Karşıtı İdeolojileri Besleme}

İdeoloji; "bir umudu, bir istenci ya da özlemi" dile getirir (Hadjinicolaou,1998, s.15). Türkiye'nin güncel ideolojik konumlanışına baktığımızda, modernite ve Batı düşmanlığında hatırı sayılır düzeyde bir yükselişle karşlaşıyoruz. Bunun ise son yılların popülist söylemlerinin etkisiyle daha da belirginleşen, eski 'mutlu' Osmanlı günlerine kavuşmaya yönelik bir istekle eklemlendiğini görüyoruz.

Türkiye'de Türklük ve Müslümanlık iç içe geçmiş kavramlar olmakla birlikte, bugünkü Yeni Osmanlıcı konjonktürde Türklük vurgusundaki Müslümanlığın çok daha yoğun bir biçimde yer aldığını görmekteyiz. Buna kaynaklık eden ümmet vurgusunun öne çıkışında ise Çanakkale Savaşı anlatısının önemli bir rolü bulunuyor. Toplumu birleştirici tarihsel bir güç olarak Müslümanlığın, Ünlü'nün ifadesi ile 'Müslümanlık sözleşmesi'nin (2018); yabanc (gayri-Müslim) düşmanlığıyla ve tehdit altında hissetme duygusuyla yoğrulmuş hınçlı bir tabana işaret ettiğini görüyoruz. Özellikle ulus devlet vurgusunun geri çekilmeye başladığı bir bağlamda bu kadim sözleşmenin daha fazla ön plana çıkması beklendik bir durum. Bu durum, Türkiye'de kitle kültürü üzerindeki etkisi gitgide belirginleşen öfke ve 'ontolojik hınç' meselelerine değinmeyi gerektiriyor. Tokdoğan Kartal'a göre "İslami muhafazakâr öznenin, hem seçkinler/halk ikiliğinde ezildiğini, bastırıldığını, hor görüldü̆̆̈̈nü hisseden milletin, hem de kimliği bizatihi imparatorluğun kaybıyla açlan yaradan doğan Türk öznesinin duygusal serüvenine; Erdoğan'ın şahsında yakından baktığımızda, karşımıza çıkan hâkim halet-i ruhiye, apaçık biçimde ontolojikleşmiş bir hınç gibi görünür" (2018, s.129). Bir lider karizmasının gölgesinde cisimleşen bu tür bir çerçevede, AKP'nin izlediği popülist stratejinin bu tür bir hıncı yansıtması olağan görünmekte.

Çanakkale destanının hiç olmadığı kadar yoğun bir biçimde Türkiye gündemine getirilmesinde; bir mazlumluk hikayesinin kitleleşmesi olarak da görebileceğimiz AKP tabanının bu tarife uyan yapısı bir etken olabilir. 
Şüphesiz ki öfke, geçmişte müesses nizamın dışında birikirken bugün düzenin ta kendisi haline gelmiş bir yapının önemli tarihsel bileşenlerinden biridir. Batı karşıtı tutum ise bu anlamda söz konusu öfkenin başlıca hedeflerinden biri halini alır. Kısacası Batı karşıtı bir konumda yer almanın, Batı'yı bir öfke nesnesi olarak yeniden konumlandıran söylemle uyumlu ve dolayisıyla hakimiyeti (ve hükümetin bugün daha da fazla ihtiyaç duyduğu destek ve rızayı) sürdürmede işlevsel olabileceğini söyleyebiliriz.

Türkiye'nin son yıllarda geçirdiği dönüşüm ve bunun yarattığı gerilimlerin Türkiye ve Avrupa (ve ABD) arasındaki gerilimleri arttırdığı görülüyor. Bunda Türkiye ile Avrupa Birliği arasındaki ilişkilerin altın çağını yaşadığ1 2000'li yılları takiben yaşanan olumsuz gelişmeler, ilerleyen yıllarda ise Arap Baharı sürecinin ortaya koyduğu yeni dinamikler ve devamında Türkiye'nin Orta Doğu politikasındaki dönüşümün etkili olduğunu görüyoruz. 2010 Anayasa Referandumu'nu takip eden süreçte; 'komsularla sıfır sorun ' politikasının geride bırakılması, Türkiye'nin dış politikasına yansıyan, bölgede söz sahibi olma vurgusu gibi gelişmelerin, hem AKP'nin yeni Osmanlıcı ideolojik konumlanışını netleştirdiğini hem de genel olarak Batı ile olan ilişkileri daha gergin hale getirdiğini söyleyebiliriz. Bununla birlikte bu metinde, konunun iç siyasete nasıl yansıdığına ve iç siyasete hakim olan Batı karşıtı popülist eğilimdeki belirginleşmenin neoliberal devlet yapılanmasıyla ilişkisine odaklanılmakta. Dolayısıyla bu tartışma, Batı karşıtı politikaları, AKP'nin iç siyaset sınırları içerisindeki manevralarının bir parçası olarak (yani ülkenin diş siyasetinden ve dünya kapitalist sistemi içerisindeki ilişkilerinden ayrı) ve Çanakkale anlatısı ile olan ilişkisi çerçevesinde ele almakta.

Çanakkale Zaferi'nin bir yanıyla; Osmanlı'nın sonunu getiren ve 1. Dünya Savaşı' $\mathrm{n} ı$ takiben Cumhuriyet'in kurulmasılla sonuçlanan sürecin bir parçası olduğu düşünüldüğünde, Osmanlı sempatizanı AKP yönetiminin bu zafer üzerindeki vurgusunun ardındaki motivasyonu anlamak zorlaşır. Hele ki Çanakkale Savaşı'nı Mustafa Kemal'in başarı öyküsü olarak tanıtan Cumhuriyet'in kuruluş dönemi resmi tarih anlatısına bakıld1ğında, bu durum daha da kafa karıştırıcıdır. "Osmanlı Devleti ve Türkiye Cumhuriyeti tarihi boyunca Gelibolu anılarının izini sürmek; Gelibolu'nun anıldığı bağlamının muharip uluslardan herhangi birisi için uzak ara en karmaşık ve en zor bağlam olduğunu ortaya koymaktadır" (Macleod, 2015, s.155). 
Bu savaş Türkiye'de, Kemalist ve İslamcı ideolojiler açısından farklı anlamlar ifade eder. Dolayısıyla İslamclığın Kemalist ideolojiden daha baskın bir konumda yer aldığı bugünkü Türkiye'de, Çanakkale Savaşı'nın, 'gerçek' kahramanlarının kim olduğuna yönelik muhtelif tartışmaların gündeme gelmesi beklendik bir sonuçtur. Nitekim, Mustafa Kemal'in savaşın sadece bir alanında, sınırlı bir görevle yer aldığı, tarih kitaplarında aksettirilenden farklı bir destan yazıldığı vurgusu son yılların özellikle hükümet yanlısı ve/veya İslamcı tarihçileri tarafından oldukça sık dile getirilir. Örneğin, Ergun Göze, 2003 tarihli Çanakkale'de Kumandanlar Savaşı adlı kitabında Mustafa Kemal'in savaştaki rolünün ne denli küçük olduğu ve üstelik savaş sırasında o güne dek üstü örtülen ciddi hatalar yaptığını vurgular (Uyar, 2016, s.178). Yavuz Bahadıroğlu ya da Mustafa Armağan gibi isimlerin Çanakkale Savaşı'nı ele alan çalışmalarında da; geçmiş tarih anlatısı kurgusunun değişmesi gerektiğine dönük bir vurgu görürüz. $\mathrm{Bu}$ kişilerin yaygın söylemlerine, Kemalist ideolojinin bilinçli olarak çarpıttı̆̆1 gerçeklerin, bu gibi çalışmalar neticesinde gün ışığına kavuşturulduğu vurgusu hakim. 'İsimsiz kahramanlar'a hak ettikleri rütbeyi iade ediyor olma iddiasındaki bu yayınlarda; geçmiş tarih anlatısının yerine bugünkü ideolojiye uygun yeni bir tarih anlatısının yerleştirilmeye çalışıldığı görülüyor. Bunun en temel işlevlerinden biri; Yavuz Bahadıroğlu'nun 2018 tarihinde yayınlanan İnancın Zaferi adlı kitabının isminde açıkça tezahür etmekte: Savaşı anlamaya dair Kemalist milliyetçi tutum yerini İslamcı, Osmanlıcı bir yaklaşıma bırakırken, yaşanan bir savaşın tarihinin güncel ideolojik hatta hizalanma amaciyla yok edilmesi, düzenlenmesi ya da yeniden yazılması. Çanakkale bu anlamda siyasal İslam'ın Türkiye siyasetini ele geçirişiyle birlikte ortaya çıan güncel kültür savaşlarının son derece önemli bir alanı. Milliyetçi bir ruhu hayatta tutmaya yarayan bir mekanizma olan Çanakkale Savaşı' nın anılma biçimi, bir zamanlar seküler bir eğilime sahipken, bugün daha dinsel bir moda bürünmüş durumda (Güler, 2016; West ve Aktar, 2018; West, 2015).

Dolayısıyla Çanakkale Savaşı; yok edilmesi değil tam aksine ön plana çıkarılması son derece işlevsel bir arka plana sahip olan tarihsel bir olay olarak öne çıkıyor. Cumhuriyet'in kuruluşundan çok kısa süre önce gerçekleşmesi ve kuruluş ideolojisini besleyen tarihsel anlatılarla bağlantısı nedeniyle güncel siyasetle iç içe ve gündeme taşıması kolay, halen Osman11 döneminde iken yaşanmış olması nedeniyle ise Kemalist ideolojiden arındırılabilir ve İslamcı ideolojiye yakın. Dolayısıyla 30 Ağustos ya da 29 Ekim tarihlerini anma törenlerinin coşkusu son yirmi yılda gitgide sönük- 
leşirken, 18 Mart Çanakkale Zaferi kutlamalarının çok daha yoğun bir biçimde ve Osmanlıcı görseller eşliğinde gerçekleştirildiğini görüyoruz. Çanakkale Zaferi'nin, Osmanlı'nın son zaferlerinden biri olarak kabul edildiğini düşünecek olursak, ${ }^{7}$ bu anlatının, AKP'nin Osmanlıcı ideolojiyi bugünkü yeni Osmanlıcı hatla birleştirme gayretiyle paralel olduğunu öne sürebiliriz. Bu bir anlamda mevcut toplumsal hafızanın başlangıç noktasını Cumhuriyet'in kuruluşundan daha geriye, Osmanlı'ya ve hatta Selçuklu'ya dayandırma çabasına da hizmet eden bir anlatı. Kısacası Çanakkale Savaşı'nın, yeni Osmanlıcı ve ümmetçi vurgular içeren Batı karşıtı yapısı ile, 'Yeni Türkiye’ projesinin kurucu siyasi anlatılarına uyum gösteren bir tarihsel referans olduğu görülüyor.

\section{Düşman Yaratma ve Hedef Şaşırtma}

Meselenin bir diğer yanı ise olgunun, -özellikle kriz durumlarında- önemli bir hedef şaşırtıcısı olarak işlev gören düşman yaratma olgusuyla olan muhtemel ilişkisidir. Neoliberal devletin ya da Wacquant'in tabiriyle ceza devletinin temel özelliklerinden biri, düşman yaratmaktır. Wacquant bunu "düşman tarif ederek yeniden toplumsal birlik yaratmak" olarak tanımlar (Wacquant ve Akçaoğlu, 2014, s.70). Dünya genelinde olduğu gibi Türkiye'de de farklı dönem ve koşullarda farklı düşmanlarla karşılaşmak sık rastlanan bir durumdur. Belli dönemlerde bir takım farklılıkların altı özenle çizilirken, bazen de daha öncesinde altı çizilen farklılıkların silikleşmesine tanık olunur.

Türkiye örneğinde, özellikle 2010 sonrası itibariyle AKP iktidarının popülist söylemleriyle yaratılan 'öteki'lerin, “halka karşı elitler” tanımı çerçevesinde birleştiği ve okların “CHP, akademisyenler, entelektüeller, hükümet karşıtı gazeteciler, Batılı güçler ve Türkiye'ye komplo düzenleyen bazı belirsiz aktörler"e yöneldiğini görüyoruz (Aytaç ve Elçi, 2019, s.99). Çanakkale Savaşı anlatısında ise; bu gruplara yönelen öfkenin ve suçlama-

\footnotetext{
${ }^{7}$ Osmanlı'nın Çanakkale Savaşı sonrasında sonuçlanan ve son zaferi olarak kabul edilen diğer savaş, Kutul-ü Ammare olarak adlandırılır (Ertaş ve Kılıçaslan, 2017). Hükümetin bu savaşı da ön plana çıkarma gayretinde olduğu 2016'da gündeme gelen 'kutlama' tartışmalarıyla kendisini göstermiştir (T24, 2016; Atay, 2016). Bu savaşı Türkiye gündeminde tutma konusundaki başarısızlığın; savaşın bugünkü Irak topraklarında yer alması nedeniyle yeterli ilgiyi yaratamamasından kaynaklandığı düşünülebilir. Uyar (2016), son yıllarda Türkiye'de görülen bu ve benzeri ideoloji kurma projelerinin, uzman tarihçilerin bu konudaki ilgisizliği ve Orta Doğu'da yaşanan politik karmaşa nedeniyle başarısızlıkla sonuçlandığını ifade etmekte (179-180).
} 
ların merkezi bir konumunda yer aldığını iddia edebileceğimiz 'Batı'nın' ön planda olduğunu biliyoruz. Batı, bu grupları algilama ve onları kitlelere bir öteki olarak tanıtma amacıyla sıklıkla referans gösterilen bir tanımlayıcıdır. 'Batı uşakları', 'monşerler', 'ajanlar' ve benzeri tanımlamalar yoluyla Müslüman olmayan Batı ülkeleriyle sıklıkla ilişkilendirilen bu gruplar; AKP'nin karşısında konumlandığı Batı yanlısı, eski seküler müesses nizamın temsilcilerine yönelik tarihsel öfkenin aktarıldığı hedeflerdir. Burada dış ve iç düşman kavramlarının da bir tür eklemlenme içerisine girdiğini söyleyebiliriz. Devlet için; yalnızca dış düşmanlar değil, onların ajanlığını yapan, devleti eleştirirken aslında onların değerlerini/çıkarlarını savunan iç düşmanlar da hedeftedir. Vatandaş, her an ve her yerde karş1laşabileceği pek çok düşmanın bulunduğu tekinsiz bir ortamda varlığını sürdürmektedir- ki bu da otoriter bir devlet yapılanması için hem yönetebilirlik/yönlendirebilirlik hem de meşruiyetinin korunması anlamında ideal bir toplumsal zemin yaratmaktadır.

Yaratılan düşmanlara, yani ötekilere yöneltilen öfkeyi, güncel popülist politikanın işlevsel bir ürünü olarak yorumlayabiliriz. Mevcut Çanakkale anlatısının bu anlamda, dolaylı olarak ülkenin bugünkü ötekilerine yüklenen suçlamaları beslediği iddia edilebilir. Üstelik bu bazen daha doğrudan bir biçimde de gerçekleşebilmektedir. Örneğin mekana atfedilen kutsallık vurgusunun İslamcı kesimdeki karşılığı olarak Çanakkale'de şehitlik bölgelerinde alkol tüketimi üzerinden yürütülen tartışmalar, siyasi arenada da bu gruplara karşı muhalefet yapmanın önemli bir aracı olmuştur. Bunu, Çanakkale'ye atfedilen kutsallığı siyasi tartışmaların odağı haline getiren biri 1962 öteki 2017 yllından iki temel örnekte görmek mümkündür. Bunlardan ilki 1962 yılında gündeme yansıyan ve CHP’ye yönelik eleştirilerin yoğunlaşmasına neden olan Kadeş olayıdır. Çanakkale Şehitliği'ni ziyaret amacıyla İstanbul'dan yola çıan Kadeş adlı vapurda yaşandığı iddia edilen alkol tüketimi ve zina gibi olaylar nedeniyle 'Kadeş rezaleti' olarak basına yansıyan olayları Armağan (2017) şu sözlerle anlatır:

Gençliği Çanakkale'yle buluşturma gezisi adıyla yapılan turda, Kadeş vapuruna sayıları 900'ü aşkın kızlı erkekli grup katıldı. Vapurda gençler karma olarak seyahat ettirildi. Yani kızlı-erkekli bin kadar genç, sözüm ona çağdaş gençlik dernekleri tarafından özel olarak seçilmişti. İşin tuhafı, gemiye yalnız genç kızlar ve erkekler değil, aşırı miktarda içki de doldurulmuştu. Düşünün, Çanakkale şehitlerini ziyarete gidiyorsunuz, anneleri babaları yanlarında olmayan bir gemi dolusu genç ve kasalarla içki alarak yola çıkıyorsunuz. Buradaki niyeti herkes gayet iyi anlayabilir. 
Bu olayın Çanakkale ruhuna sahip çıkmamakla suçlanan Cumhuriyet ideolojisiyle ve özellikle CHP ile ilişkilendirilerek aktarımına yoğun bir biçimde benzeyen bir başka olayın, 2017 yılında CHP'nin Gelibolu'da düzenlediği Adalet Kurultayı'nda yine karşımıza çıktığını ve Çanakkale Savaşı'nın İslamcı yorumlanışının bir kez daha, fakat bu kez muhalefet olarak değil hâkim ideolojinin kurucuları haline gelen iktidar üzerinden, karşıt görüşü suçlama amaciyla gündeme geldiğini görüyoruz. ${ }^{8}$ İki olayda da Çanakkale'ye atfedilen kutsallığın boyutlarını ve bu kutsallığın, Türkiye siyasetinde Batı değerleri ile ilişkilendirilen, seküler kesime yönelik öfkeye aracılık ettiğini görmek mümkün. Bu olayları aynı zamanda, Lefebvreci (1991) anlamda, kentsel mekanın siyasallığının ve ekonomi politiğinin boyutların gözler önüne seren örnekler olarak değerlendirebiliriz.

Batı'nın Türkiye üzerindeki emellerini vurgulama üzerinden, dış düşmanlara -ve aslında dış tehdit algısına- yapılan vurgunun, mevcut tarihsel korkuları pekiştiren ve dolayısıyla toplumun güvenlik algısını tetikleyen bir yanı da söz konusu. Tehdit algısının politik olarak inşa edilmesi ile toplumsal kontrol arasındaki ilişkiye odaklandığımızda ise günümüz korku kültürünü sorgulamanın önemi ortaya çıkıyor. Altheide'nin ifadesiyle korku, "öylece olan bir şey değildir; toplumsal olarak üretilir ve bundan fayda sağlayanlar tarafından manipüle edilir" (2002, s.24). Dolayısıyla korkuyu en az bireysel boyutu kadar, toplumsal boyutu çerçevesinde ele almak önemlidir. Konuya söz konusu inşacı çerçeveden bakan Neocleous, güvenliğin metalaşmasını ele alırken; korku kültüründen beslenen bir güvenlik takıntısından, 'hem sermaye ve hem de devletin fayda sağladığını' öne sürer. Güvenliği bir fetiş olarak değerlendiren düşünür, onun "hem devlet hem de sermaye için ideolojik olarak nasıl üretildiği ve geliştirildiğini yeniden değerlendirmemiz gerektiğine" dikkat çeker (2008, s.349). Yani güvenlik hem bir meta haline gelmekte -kapitalizmin sonsuz/sınırsız metalaştırma itkisinin yeni bir kurbanına dönüşmekte- hem de "devlet otoritesine toplumsal hayatı daha fazla kontrol etme imkânı vermektedir" (Şanver, 2014, s.38). Bu görüşe göre devlet, güvenlik olgusunu ve dolayısıyla tehdit algısını toplumun her alanına daha da fazla yaymaktadır. Toplumda tehdit algısının canlı tutulmasının ve güvenliğe dair kay-

\footnotetext{
${ }^{8}$ Konuyla ilgili bir haber örneği için bkz. Sabah (2017, 27 Ağustos). CHP'liler Adalet Kurultayında İçki İçti.
} 
gıların beslenmesinin ise; "hükümetlerin siyasal rıza üretim stratejilerinde küçümsenmeyecek bir rol oynadığını" biliyoruz (Bora, 2006, s.229). ${ }^{9}$

$\mathrm{Bu}$ durum toplumda, birazdan bahsi geçecek olan militarizm yorumuyla da paralellik gösteren bir duruma; yani "savaş ve barış, sivil ve askeri kavramları arasındaki farkların" bulanıklaştığı ve zaman zaman silindiği militarist bir kültüre neden olur (Sjoberg ve Via, 2010, s.7). Toplumun tamamına yayılan tehdit algısı ve korkunun, militarist bir kültürü besleyerek tüm sosyal hayata yayıldığı ve devlet otoritesinin, kontrol gücüne güç katarak gündelik hayatın bir parçası haline geldiğini görüyoruz. Güç; asker ve polisin varlığına ilaveten özel güvenlikçilerin, günümüzde bekçilerin ve hatta muhtarların denetimine yayılarak, gündelik yaşantının en ince, en küçük noktasına kadar sızmakta. Gambetti'nin ifadesiyle "devlet düzeni tanımının neoliberal düzen anlamını kazanarak pekişmesi" süreci, güç dağılımının bununla da sınırlı kalmayarak "içimizdeki hainle$\mathrm{re}^{\prime \prime}$ karşı sorumluluk sahibi vatandaşların müdahalelerine kadar uzand1ğını, Türk milliyetçiliğinin hâlihazırdaki ötekileştirici ve tahammülsüz yapısının da sınırlarını aşan bir linç kültürüne dönüştüğünü ortaya koymakta (2007, s.33). Burada genellikle 'milli refleks' olarak karşımıza çıkan kavramın 90 sonrası "bir yönelim aleti, bir 'halkla ilişkiler' politikası aracı olarak yerleşikleştirildiğini” görüyoruz (Bora, 2006, s.198). Bunu Wacquant'in sentor devlet olarak tabir ettiği devlet yapısını yansıtan, devletin neoliberal dönüşümünün bir özelliği olarak yorumlamak mümkün. Otoriterleşmenin bireyler arası ilişkilere kadar nüfuz ettiği ve cezalandırmanın yalnızca resmi kurumlar tarafından değil, bu kurumlar tarafından desteğe çağrılan 'sorumlu' vatandaşlar tarafından da üstlenildiği bir yönetim biçimi. Burada hâkim söylem; terör, savaş ve dış tehdit algısının yanı sıra içimizdeki düşmanların varlığına da işaret etmektedir.

Düşman yaratmanın riza elde etme sürecinde fayda sağlayan bu gibi özelliklerinin yanı sıra, bu düşmanın 'Batı' olmasının günümüz Türkiye'sinde bir başka işlevi daha olduğunu görmekteyiz ki bu da, yaşanan ekonomik krizlerin -çoğunlukla Batı ile özdeşleştirilen- bir dış müdahale olarak yansitılmasının getirileridir. 'Türkiye üzerinde oynanan oyunlar',

\footnotetext{
${ }^{9} \mathrm{Bu}$ aynı zamanda sosyal devlet yükümlülüklerinden geri çekilmiş bir devletin, kendi zor kuvvetlerini daha 'önemli' işler için görevlendireceği anlamına da gelecektir. Gündelik alandaki güvenlik sorunları özel güvenlik şirketlerinden satın alınırken, devletin güvenlik hizmetleri bu alandan ziyade, devletin kendisinin korunması göreviyle meşgul olur.
} 
'dış güçlere karşı milli birlik ve beraberlik içinde olma çağrısı' gibi söylemsel pozisyonlar, vatandaşın yaşanan problemlerde devletin rolüne odaklanmak yerine; bir diş tehdit algısı karşısında bir arada pozisyon almasına aracılık edebilecektir. Birbiri ardına gelen krizleri çözme konusunda eli oldukça zayıflayan yönetim için, toplumun en azından bir kesiminde oluşturabileceği bu tür bir algı, ekonomik krizin olumsuz toplumsal sonuçlarına karşı bir kalkan işlevi görebilir. Bu anlamda, söz konusu örüntüye, yani; Batılı ve Müslüman olmayan düşmanlar karşısında gösterilen direnişe tarihsel anlamda benzetilebilecek Çanakkale Savaşı kadar iyi bir başka örneğe ve tarihsel bilgi stoğuna rastlamak güçtür. Bu anlatı, yaratılan 'öteki' kitlesi karşısında ve neoliberalizmin yarattığı tekinsiz ortamda, çok daha güvenilir bir atmosfer sunan ideal bir 'biz' kimliğine dâhil olabilmenin araçlarından biridir.

\section{Hakim Rejime Destek Toplayıcı bir Araç Olarak Kullanılma ve Sadakati Pekiştirme}

Devletin vatandaşı ikna etme koşullarının zorlaşmasıyla artan otoriterleşme eğilimine; Bonefeld'in bir sözüyle bir başka boyut daha ekleyelim. Bonefeld'e göre, günümüzde "hukuka, düzene ve kurumlara yalnızca itaat etmek yeterli değildir. Aynı zamanda onları sevmek de gerekir" (2006, s.252). Paralel biçimde Türkiye'de sıklıkla duyduğumuz 'ya sev ya terk et' söyleminin milliyetçi cephe ile AKP arasındaki uzlaşıyı takiben resmi söylemde daha da yoğunlaştığını görüyoruz. Devletin neoliberal dönüşümü, bu anlamda yalnızca itaatkar değil, aynı zamanda muhafazakâr milliyetçi ideolojiyi tamamen ve gönülden benimsemiş vatandaşlara ihtiyaç duyar. Bu da, Türkiye'nin son otuz yılına damgasını vuran 'yürütmeyi güçlendirme' sürecinin en temel gerekçelerinden biri olan 'siyasi istikrar' vurgusu ile iç içedir. Bu süreçte topluma siyasal istikrar zorunluluğunu hissettirmek ise bir tehdit algısı ve güvenliğin bir değer olarak ön plana çıkarılışı ile mümkün olabilir. "Güvenliği bir değer olarak içselleştiren neoliberal özne, yaşamını resmi çevrelerin belirlediği milli güvenlik hedeflerine göre yeniden düzenler" (Gambetti, 2007, s.29). Savaş anlatılarının bu anlamda, diş ülkelerle halihazırda yaşanmakta olan krizlerle paralellik kurularak ele alınması ve bugünkü algıyı bu anlatılardan destek alarak sertleştirmesi ve militerleştirmesi de yine sürece Çanakkale'nin ideolojik katkısını ortaya koyabilir. Siyasi istikrar söylemi, devlete neoliberal dönüşümün gerekliliklerini karşılayacak altyapıyı kazandırırken, va- 
tandaşlık kavramını itaate indirgeyen ve 'düşman'lara karşı bir arada kalma odaklı tektipleştirici bir vizyona işaret eder.

Son dönem AKP propaganda araçlarında, Çanakkale vurgusunun ön plana çıkarılışı dikkate alındığında, Çanakkale ruhunun önemli bir bağlılık aracı olarak kullanıldığını ve bunun İslamiyet üzerinden netleştiğini iddia edebiliriz. Örneğin, 2015 tarihli bir videoda ${ }^{10}$ Erdoğan bizzat yer almakta ve Çanakkale Şehitliği'nde dua ederken görüntülenmektedir. Erdoğan bu videoda Müslümanlık, fedakarlık ve bağlılık duygularına hitap eden Arif Nihat Asya'ya ait Dua adlı şiiri okumaktadır. Şiirde minareler, dualar ve cihat gibi unsurların yer alması, savaşı anmada İslami unsurların ve ümmetçi anlayışın ne denli ciddi bir düzeyde ön plana çıarıldığını göstermektedir. Videonun yarattığı duygusal atmosfer içerisinde Türklük ve Müslümanlık vurgularının Müslümanlığı önceleyen bir tonda sunulduğu görülmektedir.

Bu söylemler ile bireylere empoze edilen şey; yalnızca vatanına bağll, muhafazakar ve milliyetçi vatandaşlar olmaları değil; aynı zamanda devleti (ve dinlerini) korumada aktif katılımclar konumuna gelmeleridir. $\mathrm{Bu}$ tür bir toplum mühendisliği sürecinde; tıpkı Çanakkale Savaşı sırasında olduğu gibi bugün de vatanın selameti için kendisini feda etmeye hazır bireylerin topyekûn bir seferberlik içerisine girmesi beklenir. Aynı fedakarlıklarla, kendi koşullarını hiçe sayan bireyler, dış tehditlerin gölgesindeki vatanlarının koruyucularıdır. Böylesi bir kriz sürecinde ve siyasi istikrarın bu denli önemli olduğu bir dönemde vatan daha da kutsallaşmaktadır ve kutsal olan bir şeyi sorgulamak son derece güçleşir. Dolayısıyla mevcut yönetimi sorgulamak ya da eleştirmek, birlik ve beraberliğe en çok ihtiyaç duyulan bu gibi zamanlarda vatan hainliği damgasını yemenin en kısa yollarından biri haline gelir.

\section{Savaşın Gölgesindeki Kent: Çanakkale}

Türkiye'de güncel Çanakkale Savaşı anlatısının yukarıda ele alınan üç farklı işleve doğrudan ya da dolaylı olarak katkı sağladığını öne sürdükten sonra, savaşın yer aldığı kente yani Çanakkale'ye bakalım. Yukarıda söz edilen bu zeminde; Çanakkale vurgusunun; altını çizdiği iç ve dış tehdit duygularına paralel olarak, kentte halihazırdaki militarist kültürü daha

${ }^{10}$ https://www.youtube.com/watch?v=e3it9NshuPc $(25$ Ocak 2016) 
da yoğun bir biçimde beslediği görülmektedir. Militarizmi basitçe, askerliğe ilişkin değerlerin yüceltilmesi olarak tanımlayabiliriz. Bununla birlikte "militarizmi, askeri pratiklerin sivil hayatı kapsaması olarak görmek yerine, onu savaş ve barış, sivil ve askeri kavramları arasındaki farkların bulanıklaşması ya da silikleşmesi olarak da görmek mümkündür." Bu yanıyla "militarizm ve savaş, bugün ortalama insan hayatı haline gelen şeyin bir parçasıdır. Militarizm dünyanın her yerinde; devletin siyasi operasyonlarına ve insanların gündelik hayatlarına nüfuz etmiş durumdadır" (Sjoberg ve Via, 2010, s.7).

Çanakkale, gündelik hayata yansıyan bu militarist etkiyi hissetmenin en kolay olduğu kentlerden biridir. 1462 yılında Osmanlı himayesinde bir savunma kenti olarak askeri amaçlarla kurulan bu kent, 16. yüzyıl itibariyle başlayan Ermeni ve Rum göçlerine dek asker ve bürokratların yaşadığı bir garnizon görünümündedir. 18. yüzyıldan 1910'a kadar olan süreçte ise kent büyümeyi sürdürmüş ve "savunma fonksiyonundan ziyade ticari fonksiyonuyla anılmaya başlanmıştır" (Sakarya, 2016, s.93). Sonrasında yaşanan savaş süreci ise mekanın askeri tarihsel arka planını yeniden pekiştirmiş, kent savaş ile iç içe bir görünüm kazanmıştır. Militarist yapıyı yaşatan anıların ve sonrasında da yapıların kentte yarattığı etki, kent sakinlerinin savaşı her an hatırlamasını sağlar. CHP Genel Sekreterliği'ne 1945 tarihinde sunulmuş raporda, Çanakkale halkının tüm yaşananlardan sonra kentin yeni bir savaş olasılı̆̆ında yeniden hedef haline gelebilecek olmasından duydukları tedirginlik şu sözlerle ifade edilmektedir: "Halkta kötü bir zihniyet var. Çanakkale askeri bir şehir, müstahkem bir mevkidir. Bir gün ne de olsa yanacak, yıkılacak gibi menhus, baykuş düşünceler hüküm sürüyor" (Aktaran Sakarya, 2016, s.95). Günümüzde de savaşa dair bu haletiruhiyenin kent sakinlerinin Çanakkale'yi algılama biçimlerini hala etkilemekte olduğu, savaş anlatısının savaş dışındaki konuların ele alındığı konuşmalarda dahi halen sıklıkla yer aldığı görülmektedir. ${ }^{11}$

Şehrin en merkezi noktasında bulunan topların, heykellerin ve savaşla ilgili sözlerin yer aldığı anıtların yanı sıra; son yıllarda kente Çanakkale Savaşı ile ilgili pek çok yeni yapı eklenmiş; bu yapılar hakim söylem bombardımanının da etkisiyle kentin siluetinin savaşla daha da iç içe geçmesi-

\footnotetext{
${ }^{11} \mathrm{Bu}$ bölümde yer verilen ifadeler, 2014-2018 yılları arasında Çanakkale'de yaşamış olan şahsımın kişisel gözlemleri ve bu süreçte gerçekleştirilmiş olan -kent sakinlerinin, kimlik oluşumlarını Çanakkale'nin tarihsel arka planıyla ilişkilendirme biçimlerine odaklananalan araştırmalarından elde edilen, henüz yayınlanmamış nitel verilere dayanmaktadır.
} 
ni sağlamıştır. ${ }^{12}$ Kente gelen ziyaretçi sayısı, 1990'lar itibariyle -özellikle AKP hükümetleri sonrasında basılan yayınlar (edebi eserler, turizm broşürleri, çizgi romanlar ${ }^{13}$ ) ve düzenlenen etkinliklerdeki artışların etkisiyleciddi bir yükseliş yaşamış, son yıllarda özellikle Gelibolu Yarımadası bir tür "hac merkezi" haline gelmiştir (Güler, 2016, s.308). "2005'ten bu yana bölgeye 11 yeni şehitlik inşa edilmiş; bunlar her yıl bir milyondan fazla insanın dua etmek amacıyla ziyaret ettiği popüler alanlara dönüşmüştür (bu ziyaretler büyük oranda valilikler tarafından finanse edilmektedir)". Bunun yanı sıra "bölgeye eşlik edecek açık hava camileri planları ile birlikte 15 yeni şehitlik önerisinde bulunulmuştur" (West ve Aktar, 2018). Bu da bölgeye yönelik ilginin önümüzdeki yıllarda daha da artacağını göstermektedir. ${ }^{14}$

Kentte gündelik söylemlerin söz konusu dokudan son derece etkilendiği, özellikle şehit vurgusunun bunda önemli bir yer tuttuğu görülür. "Bastığımız her yerde şehit kanı var" söylemi, kent sakinlerinin Çanakkale'yle olan bağını ifade ederken en sık kullandıkları ifadelerdendir ve kent sakinlerinin kimlik oluşumlarında bu söylemin etkisi rahatlıkla görülebilmektedir. Dolayısıyla ölüm bu söylem içerisinde önem kazanmakta; vatan için canını vermek dahil olmak üzere her türlü fedakarlıkta bulunma erdeminin yüceltilişi netleşmektedir. Çanakkale Zaferi anma törenlerinden

\footnotetext{
${ }^{12}$ Bölgede inşa edilen yeni anma merkezleri ve Gelibolu' da tartışma yaratan yol çalışmaları gibi yapısal dönüşümlerle ilgili olarak bkz. Uyar, 2016.

${ }^{13}$ Güler'in işaret ettiği gibi; Çanakkale' de "2000'lerde edebi eserler ve turizm broşürlerinde bir patlama yaşandı. Tarihsel verilere dayanma iddiası taşırken aynı zamanda bölgenin büyüyen turizm potansiyeline hitap etmeye ve bu yolla oluşan ruha ve ranta ortak olmaya çalışan yayınlar arasında uzman olmayanlar, gazeteciler ya da amatör rehberler tarafından yazılmış, içinde bölge ve savaş haritaları da içeren ucuz turizm rehberi kitapları büyük bir yer tutmaktaydı" (2016, s.331).

${ }^{14}$ Sentör devlet yapılanmasının, kentin kendisini bir meta haline getiren sermaye süreçleriyle olan ilişkisi de bu noktada incelenmeyi bekleyen önemli konulardan biridir. Türkiye genelinde olduğu gibi Çanakkale'de de, bu gibi anma merkezlerinin inşasına ilaveten, diğer pek çok alanda inşaat sektörünün etkisi gitgide daha belirgin bir hale gelmektedir. Bu yapılaşma, inşaat sektörüyle ilişkili üst sınıf çıkarlarının ve bunu destekleyen devlet politikalarının domine ettiği ve kaçınılmaz olarak kent hakkı tartışmalarını yoğunlaştıran bir yörüngede seyretmektedir. Neoliberal şehircilik ve rant kavramlarının güncel ilişkilerine değinen bir çalışma için bkz. Mayer, M. (2017) Whose city? From Ray Pah's critique of the Keynesian city to the contestations around neoliberal urbanism. The Sociological Review. 62(2). 168-183.
} 
birinde konuşma yapan yüksek rütbeli bir komutanın ifadesiyle "Çanakkale ölmesini bildikleri için yaşamaya hak kazanan insanların haysiyet mücadelesidir" (Gürler, Özer ve Yetişkin, 2016, s.76). Ve bu mücadelenin anısı, bugünün vatandaşlarından beklenen yeni fedakârlıklar için bir referans kaynağıdır.

\section{Sonuç Yerine}

Sosyal bilimler, hakim söylemlerin dokusunu oluşturan kategori ve konuların sistemli eleştirisi yoluyla, bugünkü gidişatı ve ona içkin eğilimleri doğallaştıran yeni neoliberal ortak aklı çözücü bir rol üstlenebilir. Bu, mümkün olan en yüksek sayıda insana toplumsal dünya hakkında kendi düşüncelerini geri alabilmeleri için gereken tefekküre sahip olmalarında gerekli araçları verebilme meselesidir. Böylece (onlar) önceden üretilmiş fikirlerle işgal edilmiş kitle iletişim araçları yoluyla düşünmemiş olurlar[...](Wacquant, 2009b, s.129).

Neoliberalizmin bugünkü paradokslarının yeni olmadığını, kapitalist sistemin 19. yüzyıldan bu yana yarattı̆̆ çelişkilerle benzerlik gösterdiğini söylemek mümkündür. Bununla birlikte, üretimin ve tüketimin değişen doğası, sürece devletin daha da fazla eklemlenmesi, uluslararası sermayenin serbestçe dolaşımı ve gelişen teknoloji gibi faktörler düşünüldüğünde, bugünkü paradoksların yapısının çok daha karmaşık olduğu ortadadır. Bu aynı zamanda, devletin sermayeyi ve piyasanın hareket alanını koruma misyonunu üstlenen bir yapıya dönüşmesi nedeniyle çok daha saldırganlaştı $\breve{1}$ ve otoriterleştigi bir süreci ifade etmektedir. 2008 krizinden bu yana daha da çok tartışıldığı üzere, mevcut sistem içerisinde artık tutarlı bir yönetim anlayışı, hayat/iş güvencesi ve kestirebilir bir sosyal hayata erişmek mümkün görünmemektedir. Bu koşullar, farklı ülkelerde farklı otoriter popülizmlere alan açan, kitlelerin karizmatik liderlerin güdümünde kaybettikleri güvenlik hissini ve 'biz' algısını yakalamaya çalıştıkları, karmaşık ve şiddete meyilli bir toplumsal arena yaratır.

Piyasa koşullarının etkisi altında var olan bir iktidarın gücü, toplumu hizada tutabileceği mekanizmaları bulabilmesi ve bu anlamda işe yarar anlatılar yaratabilmesine bağlı görünmektedir. Mevcut koşullardan etkilenen kitlenin kalabalıklığı düşünüldügüüde (ve aynı zamanda bu kitlenin mevcut sistemin potansiyel emekçileri ve tüketicileri olarak kalması gerektiğinden) bunu yalnızca zor kullanarak yürütmek mümkün görünmemektedir. Dolayısıyla zor kullanmaya alternatif oluşturabilecek ve devletin 
otoriterleşen yapısına uyum gösterecek kitleler inşa etmeye yarayacak cazibede ve bağlayıcılıkta ideolojiler yaratmak önem kazanır.

Zorlu ekonomik koşullar altında bir toplumu yönetebilmek ve piyasa koşullarına göre her an değişebilecek olan uygulamaların sorgulanmadan kabullenilmesini sağlamak, topluma korku ve biat kültürünü mümkün olduğunca yoğun bir biçimde aşılayabilme becerisi gerektirir. Wacquant'ın, devletin neoliberalleşme sürecinde küçülmediği fakat şekil değiştirdiği ve daha da otoriterleşen bir ceza devletine dönüştüğünü ifade eden kuramsal tartışması bu eğilimle paralel bir görünüm sergiler. Devletin güçlenmesi, hakim ideolojiyi (ya da popülist söylemleri) besleyen, kitleyi tektipleştirici ve dışarıda kalan kesimi dışlayıcı anlatıların başarısıyla yakından ilişkilidir. Bu süreçte, yani yeni anlatılar yaratılırken, her dönem olduğu gibi, yine tarihsel referanslardan yararlanmak olmazsa olmazdır.

Global düzeyde, muhafazakar partilerin bugünün neoliberal ihtiyaçlarına en iyi karşlık verebilen aktörlere dönüştüğünü görüyoruz. Mevcut karmaşaya; milliyetçilik, yabancı düşmanlığı, ırkçılık ve muhafazakarlığın eşlik ettiğini ve bu ideolojilerin toplumu böylesi eşitsiz ve tekinsiz bir sistem içerisinde yönetmeyi sürdürebilme anlamında cazibesini koruduğunu iddia edebiliriz. Dolayısıyla bu metinde, mevcut koşulların muhafazakarlaşmayı doğurduğu iddiasından ziyade; muhafazakarlaşmada yükselişin, mevcut koşullara son derece uygun ve koşulların doğurduğu ikna ihtiyacını karşılamada etkin bir yönelim olduğu ve bunun büyük oranda tepeden aşağıya doğru pompalanan ideolojiler/popülist söylemlerle gerçekleştiği öne sürülmüştür. Bununla birlikte, söz konusu süreci ilişkisel bir biçimde değerlendirmek gerekir. Dolayısıyla yalnızca tepeden gelen bir muhafazakarlaşmadan değil, halihazırda mevcut bağlamın tarihsel arka planından da beslenen; yukarıdan gelenle aşağıda potansiyel olarak korunan arasındaki tarihsel ilişkiyi canlandıran ve restore eden bir eğilimden bahsedebiliriz. Bu da hakim söylemlerin, dün ve bugün arasında mekik dokuması ve yenilenen/güncellenen tarihsel anlatılar yoluyla farklı formlarda gündeme taşınması anlamına geliyor.

Wacquant külliyatının da aksettirdiği gibi, neoliberalleşmenin şekil verdiği devlet yapılanmasının, bu karmaşık tahakküm ve meşrulaştırma biçimleriyle ilişkisi ancak sembolik, fiziksel ve toplumsal uzam arasındaki dinamik ilişkiyi gözeterek anlaşlabilecektir. Bu çerçevede metinde, neoliberal iktidar pratiklerinin günümüz Türkiye'si bağlamına yansımaları Çanakkale örneği üzerinden incelenmiştir. Neoliberal uygulamaların, or- 
tak motivasyonları nedeniyle dünya genelinde görülen otoriterleşme ve şiddetin yaygınlaşması gibi sonuçları, Türkiye'de de benzer örüntülerle karşımıza çıkmaktadır. Bununla birlikte metinde Türkiye'ye, neoliberal uygulamaların bu coğrafyaya özgü siyasi geleneklerle ilişkisinden doğan karmaşa gözetilerek bakılmıştır. Wacquant'ın otoriterleşen devlet kavramsallaştırmasında ele alınan ceza ve kapatma (incarceration) vurgusu Amerika örneğinin etkisiyle çok daha yoğun bir yer tutarken, Türkiye'de cezalandırma alt sınıflardan ziyade, hükümete muhalefet eden -çoğunlukla orta sinıf- gazeteci, akademisyen, entelektüel ya da sivil toplum örgütü üyeleri gibi gruplar için daha yoğun bir artış göstermiştir. Türkiye'de alt sınıfların hizada tutulması yüksek düzeyde kapatmaya gerek kalmadan, büyük oranda bu metinde örneklendirilen ideolojik kapatma biçimleri çerçevesinde gerçekleşmektedir. Bu kesimlerin hakim ideolojiye uyum sağlamalarına söylemleri ya da eylemleri yoluyla engel oluşturabilecek gruplara yönelik cezalandırma biçimleri, alt sınıfları bu ideolojik kapatma içerisinde tutmaya şimdilik yeterli görünmektedir.

Elbette neoliberalleşmenin Türkiye'yi tamamen yeni bir toplumsal yapıya dönüştürdügünü söylemek mümkün değildir. "Neoliberal hükümetler, geçmiş hükümetlerin program ve stratejilerini yeniden dolaşıma sokmaya ve onların eski parçalarını yeniden kullanmaya meyillidir" (Woolford ve Nelund, 2013, s.298). Dolayısıyla bugünün yapılanması ile geçmiş yapılar arasında pek çok paralellik bulunabilir. Bununla birlikte bu metinde, bugünün Türkiye'sine özgü olduğunu öne sürebileceğimiz eğilimlerden söz ettim. Wacquant'in sentor devlet olarak tarif ettiği neoliberal devlet yapısının Türkiye'deki görünümüne göz atarak, kente yönelik tarihsel ideolojik atıfların; güncel durumun/yeni müesses nizamın kurulmasına, şekillenmesine ve korunmasına nasıl katkı sağlıyor olabileceğini sorguladım. Böylece Çanakkale örneği üzerinden, kentte yaşanan savaşa atfedilen güncel değerleri ve bu değerlerin son yıllarda eskisinden çok daha yoğun bir biçimde öne çıkarılışını anlamaya çalıştım. Bunun yukarıda anlatılan neoliberal koşulların yarattığı ihtiyaçları karşılama amacıyla vurgulanan; toplumu hizaya sokucu normatif bir projenin işlevsel bir unsuru olarak yorumlanabileceğini öne sürdüm. Bu analiz ışığında, Çanakkale örneğinden yola çıkarak, Türkiye'de kent ile neoliberal devlet inşası arasındaki ilişkiyi anlamaya yönelik yeni ve daha kapsamlı araştırmalara duyulan ihtiyacın altını çizmek gerekir.

Savaşı hatırlamanın, pek çok farklı yolu ve işlevi bulunur. Kitlelere sunulan/empoze edilen kaynaklara ve hakim ideolojik söylemin savaşı ele 
alma biçimine göre toplumlar, savaşa karşı ne hissedeceğini öğrenir. Savaşın yer aldığ 1 kentlerin bu söylemlerden çok daha yoğun bir biçimde etkilendiği ve bu söylemlerin söz konusu kentlerin kimliğinde cisimleştiği görülmekte. Bu yolla mekan kutsallaşmakta ve siyasallaşmakta, aynı zamanda toplumdan beklenen tutum ve davranışlar bu söylemler aracilığıyla şekillenmekte ve dillendirilmektedir.

Savaşın hatırlanma biçimi hakim ideolojinin yapısını ortaya serer. Savaşı, bir daha asla yaşanmaması gereken, insan hayatının ve barışın tüm çıkarların üzerinde bir anlam taşıdığını ifade eden evrensel barış söylemi çerçevesinde yorumlamak mümkündür. Oysa dünyanın pek çok yerinde olduğu gibi Türkiye'de de savaş, yaşanan tüm acılara ve kayıplara rağmen hala milli kimlik yaratıcı, ayrıştırıcı ve dolayısıyla hem iç hem de diş siyasette yeni gerginliklere neden olma riski taşıyan bir hat üzerinden ele alınır. Bu ise savaşta yaşamını kaybeden insanların canlarını feda ederken hissettikleri muhtemel ideallerin çok uzağına düşen, toplumu kutuplaştıran ve yeni ölümlere yol açacak gerginlikleri besleyen son derece tehlikeli bir stratejidir. Çanakkale Savaşı özelinde ilgi çekici görünen bir diğer nokta ise, bu savaşın Batı karşıtı güncel siyasi söylemi beslerken; aynı zamanda küresel güçlerin ekonomik çıkarlarına hizmet eden neoliberal otoriter bir devlet yapılanmasının meşrulaştırılmasına hizmet ediyor olmasıdır. 


\title{
Extended Abstract
}

\section{A Discussion on the Role of the Gallipoli War Narrative in Constructing and Protecting the Neoliberal Government in Turkey}

\author{
Elif Gezgin \\ Lund University / Çanakkale Onsekiz Mart University
}

In this paper, I examine why the Gallipoli War narrative has become increasingly important in the discourse of the JDP (Justice and Development Party) governments over the last two decades, and how this visible tendency is related to the construction and protection of the neoliberal government in Turkey. I frame the discussion by utilizing Loï Wacquant's concept of the "centaur state" and focus on how Gallipoli narratives meet the requirements of the neoliberal order in contemporary Turkey. I argue that in the Turkish case, there is an ideological incarceration, in addition to incarceration, which helps the centaur state to obtain and protect its legitimacy. The Gallipoli War narrative acts as a significant historical reference to enable this current ideological incarceration of Turkish society, specifically by: i) supporting anti-Western ideologies; ii) creating enemies; and iii) providing political support for the dominant regime.

Like many other countries, Turkey since the 1980s has suffered the devastating effects of neoliberalism, especially in respect of labor rights and working conditions. This process served to gradually diminish the living conditions of lower- and working-class citizens. Over the course of the last two decades in Turkey, this trajectory has been exacerbated by more aggressive privatizations and harsher deregulations. Currently, these developments have resulted in a deeply unequal distribution of resources alongside a shift in the political regime and an economic crisis. In such an atmosphere, where the centaur state has been 'fatherly' pampering the upper classes and ill-treating the lower classes, one of the government's priorities has been to control the lower-class masses and to 
keep them under constant surveillance. Against this background, I analyze the functions of the Gallipoli War narrative. I seek to answer my research question by studying a local case and drawing on the scholarship on neoliberalism, as well as interrogating the relationship between the power relations and the way history is passed down from one generation to the next and from the state to the public.

Populist discourses, which appeal to the emotions of the majority or mainstream, play a significant role in the construction and protection of neoliberal governments. Historical narratives are vital elements in this respect and they always come to the rescue while shaping these populist discourses in accordance with the expectations and requirements of the dominant regimes. The Gallipoli War narrative is significant in a variety of ways in the context of contemporary Turkey. First of all, the narrative forms a very fruitful ground on which to build up anti-Western sentiment. Considering the growing power of the Turkish-Islamic synthesis in recent decades, we see that this ideological perspective is intertwined with and gaining strength from the historical feeling of being under threat from Western powers. The Gallipoli narrative perfectly taps into these feelings as clear proof of the historical existence of this threat. It simultaneously reinforces the sense of being under threat and evokes pan-Islamist sentiments. Like all authoritarian regimes, the current government in Turkey seeks to govern in a way that creates a climate of fear, which sends ripples through society. Creating enemies is also important in this respect - especially in times of crisis. The nationalist and Islamist spirit - empowered by 'Çanakkale spirit' - does not just target the West per se, ${ }^{15}$ it also attacks opposition groups/political parties, academics, journalists, and intellectuals who are frequently labeled as 'servants of the West', 'spies of the West', or 'mon chers'. ${ }^{16}$ Such anger and rage - that is reinforced by the invocation of the Gallipoli narrative - is politically useful on three counts. First, it helps to criticize and repel opponents while legitimizing the practices of the state of emergency (at the same time targeting academics, journalists, etc.). Second, it creates an atmos-

\footnotetext{
${ }^{15}$ If it were only targeting the West, it would be appropriate and necessary to refer to the justifiable reasons behind anti-Westernism in this territory here, rather than focusing on how the neoliberal state uses this threat to manipulate the masses.

${ }^{16}$ A French word (meaning "my dear") frequently and sarcastically used by President Erdoğan in referring to a group of elitist, Westernized people who neither care about nor understand the "real" Turkish society.
} 
phere of imminent threat, which puts citizens on the lookout for an attack by external powers or the latter's co-conspirators within (who constitute the regime's internal scapegoats). As a result of this typical paranoid style of politics - which permeates society with the conditions of a police state - frightened masses seek out powerful leaders - those who are willing to defend them against all these enemies. As a result, the masses unequivocally support such figures and regimes for the sake of stability. Third, this discourse is useful for creating and strengthening alternative discourses that serve to absolve the government of any responsibility for the country's economic crisis. Stressing that all these economic problems are merely part of a game that the West plays with our country both relieves the government of taking responsibility for its neoliberal policies and deceives the masses about the structural problems related to the economic crisis.

Another role of the Gallipoli War narrative is to act as a tool to provide political support to the dominant regime. There has been a kind of discursive battle over the Gallipoli War, which has emerged between supporters of the Turkish secular/Kemalist groups and those of the current conservative government. The war was presented to society as a chiefly secular struggle and as a complementary part of today's Republican ideology; today, it is presented as a religious struggle and as a complementary part of an unfinished story of the great Ottoman power in a pan-Islamist mode. In the contemporary context, the war is served as a kind of jihad of Muslims instead of one of the first victories of Mustafa Kemal, which opened the way to a secular Turkish Republic. This kind of religious narration of the Gallipoli War clearly supports the image of the president and the JDP's conservative regime (similarly to how the same war's secular narrative was used to support the image of the Kemalist regime in the past). A careful analysis of news, promotional online videos, and the electoral speeches of Erdoğan (which were used for the JDP's electioneering campaigns and campaigns during the presidential elections) clearly demonstrates that the Gallipoli War narrative features prominently in such campaigns.

All in all, this paper argues that the way in which the neoliberal government achieves domination in Turkey is not just limited to the extension of the penal state and incarceration. It also happens through a kind of ideological incarceration of the society, by constructing discourses with the help of historical narratives - like the Gallipoli War. This war narra- 
tive -which reinforces nationalist, conservative, and militarist states of mind - is an inevitable part of this ideological incarceration as religion and nationalism - as the country's main building blocks - are easily fused together under the umbrella of this narrative. Thus, they garner consent and support from society up to the required standard, despite the extremely volatile conditions that would otherwise have the potential to create civil disorder. As such, the Gallipoli War narrative becomes one of the most important sources for the government in order to meet the requirements of building both religious and nationalist citizens who are ready to sacrifice themselves for the sake of the continuity of the state (and of capital) and ignore the state's role in the daily economic and social challenges they face. Fueling rage and fear in these populist discourses misleads society and distracts the public's attention, and as a result, society continues to give consent to the authoritarian regime which works hand in hand with the market economy and serves the interests of particular lobbying groups (most of which have connections with members of the government). In this atmosphere, whereby the masses are kept under ideological and authoritarian control, the only "trouble-making" groups left are journalists, academics, and other intellectuals who have the potential to break the silence, unveil the illusions, and force the government to fix the problems rather than creating and targeting enemies. In response to this threat, the neoliberal penal state in Turkey mostly targets these groups instead of directly imprisoning the poor. It severs Turkish society's connection to the outer world by preventing people from accessing alternative news and information sources, thereby ensuring the sustainability of the ideological incarceration of the society.

What is ironic in this scene is how conservatism, nationalism, and anti-Western strategies are utilized as mechanisms to protect a cruel, neoliberal order, which derives from the West and merely serves global that is, international - powers.

\section{Kaynakça/References}

Akçaoğlu, A. ve Wacquant L. (2014). Loïc Wacquant ile söyleşi: Kentsel marjinallik, devletin sağ eli, Birikim, 298, 67-72.

Aktar, A. (2017, 25 Temmuz). Rewriting the history of Gallipoli: A Turkish perspective. Honest History. 
Altheide, D. L. (2002). Creating fear: News and the construction of crisis. New York: Aldine De Gruyter.

Arın, T. (2007). Türkiye'de mali küreselleşme ve mali birikim ile reel birikimin birbirinden kopması. A. Köse, F. Şenses ve E. Yeldan, (Der.). Küresel düzen: Birikim, devlet ve sınıflar içinde (ss. 569-610). İstanbul: İletişim.

Armağan, M. (2017, 29 Ağustos). CHP’nin Çanakkale rezaleti ilk değil. Yeni Akit. Atay, T. (2016, 22 Nisan). Bir 'Yeni Türkiye' icadı: Kut'ül Ammare. Cumhuriyet.

Aytaç S. E. ve Elçi E. (2019). Populism in Turkey. D. Stockemer (Der.) Populism Around the World. Cham: Springer.

Bedirhanoğlu, P., Dölek, Ç. ve Hülagü, F. (2016). Eleştirel güvenlik çalışmalarının Marksist eleştirisine katkı: Devlet, zor ve sınıf mücadelesi bağlamında "güvenliği" yeniden düşünmek. Praksis, 40, 9-40.

Bedirhanoğlu, P. (2009). Türkiye'de neoliberal devletin AKP’li yüzü. İ. Uzgel ve B. Duru. (Der.) AKP kitabı: Bir dönüşümün bilançosu içinde (ss. 39-64). Ankara: Phoenix.

Bedirhanoğlu, P. ve Yalman, G. L. (2009). Neoliberal küreselleşme sürecinde Türkiye'de 'yerel' sermaye: Gaziantep, Denizli ve Eskişehir'den izlenimler. Praksis 19, 241-266.

Bedirhanoğlu, P., Çelik, Ö. ve Mihcı, H. (2017: 14). Giriş. P. Bedirhanoğlu, Ö. Çelik, H. Mihcı (Der.) Finansallaşma kıskacında Türkiye'de devlet, sermaye birikimi ve emek içinde (ss. 11-23). İstanbul: Notabene.

Bonefeld, W. (2006). Democracy and dictatorship: Means and ends of the state, Critique, 34 (3), 237-252.

Bora, T. (2006). Medeniyet kaybı: Milliyetçilik ve faşizm üzerine yazılar. İstanbul: Birikim.

Bora, T. (2007). Bu sayıda. Toplum ve Bilim, 109, 3-7.

Ertaş, M. Y. ve Kılıçaslan, H. (2017). Kutül Amare 1916: Olaylar, hatıralar, raporlar. İstanbul: Kronik.

Gambetti, Z. (2007). Linç girişimleri, neoliberalizm ve güvenlik devleti. Toplum ve Bilim, 109, 7-34.

Gamble, A. (2006) Two faces of neo-liberalism. (Der.) R. Robison. The neo-liberal revolution: Forging the market state içinde (ss. 20-35). London: Palgrave.

Güler, Z. E. (2016). Bir ulusal hafıza mekanı olarak Gelibolu yarımadası. İ. Ö. Kerestecioğlu ve G. G. Özvatan (Der.), Türk sağı: Mitler, fetişler, düşman imgeleri içinde (ss. 307-345). İstanbul: İletişim.

Güngen, A. R. (2017). Finansal tabana yayılma siyaseti ve Türkiye'de devletin finansallaşması. P. Bedirhanoğlu, Ö. Çelik, H. Mihcı (Der.) Finansallaşma kıskacında Türkiye'de devlet, sermaye birikimi ve emek içinde (ss. 23-45). İstanbul: Notabene.

Gürcan, E. C. ve Mete, B. (2017). Neoliberalism and the changing face of unionism: The combined and uneven development of class capacities in Turkey. Palgrave Macmillan. 
Gürler, E. E., Özer, B. ve Yetişkin, E. (2016). Hafızanın arayüzü olarak anma ve anma mekanları: Gelibolu yarımadası örneği. Mimar.İst, 56.

Haspolat, E. (2016). Yasamadan yürütmeye iktidar devri olarak torba yasama. Alternatif Politika, 8(2), 404-449.

Herr, H. ve Sonat Z. M. (2014). The fragile growth regime of Turkey in the post2001 Period. New Perspectives on Turkey, 51, 35-68.

Kılıç, S. (2014). Liman von Sanders'in Çanakkale Savaşları ile ilgili bazı iddiaları, Akademik Bakış, 7(14).

Hadjinicolaou, N. (1998). Sanat tarihi ve sınıf mücadelesi (M. H. Spatar, Çev.). İstanbul: Kaynak.

Lefebvre, H. (1991). The production of space. Oxford: Blackwell.

Macleod, J. (2015). Great battles: Gallipoli. Oxford: Oxford University Press.

Mason, P. (2016). Kapitalizm sonrası geleceğimiz için bir kılavuz. (Ş. Alpagut, Çev.). İstanbul: Yordam.

Neocleous, M. (2007). Security, commodity, fetishism. Critique: Journal of Socialist Theory, 35 (3): 339-355.

Sakarya, İ. (2016). Katılımo demokrasi ve kent hakkı çerçevesinde Çanakkale'de yerel siyaset. (Yayınlanmamış Doktora Tezi), İstanbul Üniversitesi, İstanbul.

Sjoberg, L. ve Via, S. (2010). Introduction. L. Sjoberg ve V. Sandra Der. Gender, war and militarism, Feminist perspectives içinde (ss.1-17). Oxford: Praeger.

Şanver, A. (2014). Turkish state as a "neoliberal leviathan" under the AKP rule: The case of private security companies. (Yayınlanmamış Yüksek Lisans Tezi), İstanbul Şehir Üniversitesi, İstanbul.

Tokdoğan Kartal, N. (2018). Türkiye'de sembolik siyasetin duygusal tezahürleri: Yeni Osmanlıc anlatının duygu hazinesi (Doktora Tezi), Hacettepe Üniversitesi, Ankara.

Tolstoy, L. N. (1922). Anna Karenina. New York: Charles Scribner`s Sons.

T24 (2016, 17 Nisan). Sözcü: MEB, Osmanlı'nın kazandığ1 Kut'ül Ammare savaşınının yıldönümünde kutlama talimatı verdi.

Uyar, M. (2016). Remembering the Gallipoli Campaign: Turkish offical military histography, war memorials and contested ground. First World War Studies, 7( 2), 165-191.

Uzgel, I. (2006). AKP: Neoliberal dönüşümün yeni aktörü. Mülkiye Dergisi, 30(252), 7-18.

Ünlü, B. (2018). Türklük sözleşmesi. Ankara: Dipnot.

Wacquant, L. (2007). Territorial stigmatization in the age of advanced marginality. Thesis Eleven, 91 (1), 66-77.

Wacquant, L. (2009). Punishing the poor: The neoliberal government of social insecurity. ABD: Duke University Press.

Wacquant, L. (2009b). The body, the ghetto and the penal state. Qual Sociol, 32, 101-129. 
Wacquant, L. (2010). Crafting the neoliberal state: Workfare, prisonfare, and social insecurity. Sociological Forum, 25 (2),197-220.

Wacquant, L. (2012). Three steps to historical anthropology of actually existing neoliberalism. Social Anthropology, 20, 66-79.

Wacquant, L. (2014). Marginality, ethnicity and penality in the neo-liberal city: An analytic cartography. Ethnic and Racial Studies, 37(10),1687-1711.

West, B. (2015) Re-enchanting: Nationalisms, rituals and remembrances in a postmodern age. New York: Springer.

West, B. ve Aktar, A. (2018, 24 Nisan). Gallipoli commemorations of Turkish youth tell us much about politics in Turkey. The Conversation.

Woolford, A., ve Nelund, A. (2013). The responsibilities of the poor: Performing neoliberal citizenship within the bureaucratic field. Social Service Review, 87(2),292-318.

Yazıcı, B. (2013). Güncel sosyal bilim analizinin sihirli anahtarı: `Neoliberalizm`? Toplum ve Bilim, 128,7-31.

Zedner, L. (2009). Security. Oxon: Routledge.

Elif Gezgin Anadolu Üniversitesi Yabancı Diller Eğitimi Bölümü'nden 2007, Sosyoloji Bölümü'nden (Yandal) ise 2006 yılında mezun oldu. Doktora derecesini Anadolu Üniversitesi, Sosyoloji Bölümü'nden 2015 yılında aldı. Gezgin, doktora sonrası araştırmacı olarak Lund Üniversitesi, Sosyoloji Bölümü'nde çalışmakta; aynı zamanda Çanakkale Onsekiz Mart Üniversitesi Sosyoloji Bölümü'nün akademik kadrosunda yer almaktadır.

Elif Gezgin graduated from Anadolu University, the Department of Foreign Language Education and the Department of Sociology (Minor) in 2007 and 2006, respectively. She obtained her PhD degree in Sociology from Anadolu University in 2015. She is currently a post-doctoral researcher at Lund University and also a faculty member of the Department of Sociology at Çanakkale Onsekiz Mart University.

E-mail: egezgin@comu.edu.tr 